\title{
Türk Resminde Bir Sanat Dehası: İbrahim Çallı
}

\section{An Art Genius in Turkish Painting: İbrahim Çallı}

\section{Şemseddin Ziya Dağlı}

Doç. Dr., Akdeniz Üniversitesi, Güzel Sanatlar Fakültesi, Grafik Bölümü

email: szdagli@hotmail.com (DORCID ID: https://orcid.org/0000-0003-3085-2979

\begin{abstract}
$\checkmark$ iThenticate' Bu makale bilimsel etik ve kurallara uygun hazırlanmış ve intihal incelemesinden geçiririlmiştir. Etik kurul onayı gerektirmemektedir.

Atıf (APA 7)/To cite this article

Dağlı, S.. Z. (2021). Türk resminde bir sanat dehası: İbrahim Çallı. Atatürk Üniversitesi Güzel Sanatlar Enstitüsü Dergisi, 27(47), 489-497. https://doi.org/10.35247/ataunigsed.935291
\end{abstract}

Makale Gönderim Tarihi/Received: 11/05/2021

Makale Kabul Tarihi/Accepted: 26/10/2021

Makale Yayın Tarihi/Published: 28/10/2021

Review Article / Derleme Makale

$\ddot{O ̈ z}$

İbrahim Çallı, Türk resim sanatının ekol isimlerinde biri olan ve bir döneme ismini yazdırmış Türk resim sanatçısıdır. Çallı, Osmanlı Devleti'nin son dönemlerinde (1914 öncesi) Fransa'daki sanat eğitimini yarıda keserek Anadolu'ya geri dönmüş ve yaptığ 1 sanat çalışmaları ve kurduğu sanatçı grubu ile bir savaş döneminde (I. Dünya savaşı) dahi adını duyurmayı başaran, sanatı ve renkli kișiliği ile sanat camiasının örnek aldığı öncül Türk sanatçılarından olmuştur. İçinde bulunduğu ve üyesi olduğu milletin genel özelliklerinin yanı sıra Cumhuriyetin ilanı sonrası çağdaşlaşma yolundaki Cumhuriyet devrimlerini benimsemiş, çağdaş resimleri yanında toplumun yaşamını, memleketin doğasını ve devletin kurucusu Atatürk'ün portresini, atanın isteği ile yapmış bir sanatçıdır. Modern, özgün, toplumcu, renkli, hoş sohbet ve izlenimci resimlerin ressamıdır Callı. Bu araștırmada Türk ressam İbrahim Çallı'nın çok yönlülügü ve Türk resim sanatına katkıları araştırılmıștır.

Anahtar Kelimeler: İbrahim Çallı, Resim, Empresyonizm

\begin{abstract}
İbrahim Çallı is a Turkish painting artist who is one of the prominent names of Turkish painting art and had his name written in a period. He interrupted his art education in France in the last periods of the Ottoman Empire (before 1914) and returned to Anatolia and succeeded in making a name even in a war period (World War I) with his artworks and the artist group he founded. With his art and colorful personality, he became one of the leading Turkish artists, taken as an example by the art community. He was an artist who adopted the Republic's revolutions on the way to modernization after the proclamation of the Republic as well as the general characteristics of his nation and painted the life of the society, the nature of the country, and the portrait of Atatürk, the founder of the state, with his request. He was the painter of modern, original, socialist, colorful, pleasant conversational, and impressionist paintings. In this research, the versatility of the Turkish painter İbrahim Çallı and his contributions to Turkish painting art were examined.
\end{abstract}

Keywords: İbrahim Çallı, Painting, Impressionism

\section{Giriş}

14 kuşağı ya da Çallı kuşağı adıyla anılan, kurtuluş savaşı döneminde sanat kuşağına adını veren, gerek yaşadı̆̆ dönemde ve gerekse Türk resim sanatında bir ekol olan, günümüz Türk resim sanatında büyük paya sahip ve birçok büyük Türk sanatçısı yetiştirmiş çok renkli bir kişiliktir İbrahim Çallı. Osmanlı devletinin Tanzimat Fermanı ve akabinde Islahat Fermanı ile başlayan batılılaşma hareketleri neticesinde Batı tarzı resim sanatının gelişmesini sağlamıştır. Batı tarzı resim sanatının gelişimi için kabiliyetli öğrenciler resim eğitimi almak için Londra, Paris, Berlin ve Viyana gibi şehirlere gönderilmiştir (Papila, 2008, s. 121).

Tanzimat'la başlayan ve sürekli gelişen Türk resmi, batıda önemli şehirlerde eğitim alan sanatçıların dönmesi ile farklı bir boyuta girmiştir. Özellikle I. Dünya savaşı döneminde yurda dönen sanatçıların katkısı göz ardı edilemeyecek kadar barizdir. Osmanlı Devleti Sanayi-i Nefise Mekteb-i Âlîsi’nde resim eğitimi alan İbrahim Çallı, Feyhaman Duran, Nazmi Ziya Güran, Ali Sami Boyar, Sami Yetik, Mehmet Ruhi Arel, Namık İsmail, H. Avni Lifij, Mehmet Ruhi Arel resim eğitimi almak için Paris’e Academie des Beaux Arts’a gönderilmiştir. Resim eğitimlerinin ardından 1914 yılında yurda geri döndükleri için, dönüş yılına atfen "1914 Kuşağı Ressamları" denilmiştir. Resim sanatına getirdikleri izlenimci resim yeniliklerinden dolayı da Türk İzlenimcileri ismiyle bilinirler (Baytar ve Okkalı, 2020, s. 126). Osmanlı Devleti’nin son dönemi ile Cumhuriyetin ilk yılları arasında bir geçiş olan "1914 Kuşağı" Türk resminde gerçek bir dönüm noktası oluşturmuştur. Batı tarzı resim sanatına geçişi sağlayan kurum ise hiç şüphesiz Sanayi-i Nefise Mekteb-i Âlîsi olmuştur. Batı'ya eğitime gideler arasında dikkati çeken bir sanatçı vardır, o da Çallı'dır. Bir dönem adını verecek olan Çallı'nın mektepte eğitim aldığ yılların müdürü ise Türk sanatının öncüsü Osman Hamdi Bey'dir. Çallı'nın hocaları arasında ise Salvator Valeri, Warnia Zarzecki ve Ömer Adil gibi sanatçılar yer almaktadır (Berk ve Özsezgin, 1983, s. 15).

1914'te Paris'te aldığı eğitimi tamamlayarak yurda dönen Çallı, Sanayi-i Nefise Mektebi’nde 1947'ye kadar hocalık yapmıştır. Bedri Rahmi Eyüboğlu, Zeki Kocamemi, Muhittin Sebati, Hale Asaf, Halil Dikmen, Cemal Tollu, Eşref Üren, Nurullah Berk, Refik Epikman, Avni Çelebi, Cevat Dereli, Mahmud Cüda, Nuri İyem, Şefik Bursalı gibi Türk resminin kilometre taşlarından sayılan ressamlara hocalık yapmıştır (Eyüboğlu, 1976, s. 9). 
Yetiştirdiği sanatçılar ve sanatı ile Türk resim sanatında haklı bir yere sahip olmuştur. Dönemin sanatçıları arasında türlü nedenlerden dolayı ismini en çok duyuran, yaygın bir üne kavuşan ve bir orkestra şefi gibi parlayan Çallı, günün birinde ülkenin en ünlü sanatçısı olacağını belki de hayal bile etmiyordu.

\section{Yöntem}

Bu araştırma betimsel modele dayalı nitel bir arştırmadır. Araştırma kapsamında Türk ressam İbrahim Çallı'nın çok yönlülüğü ve Türk resim sanatına katkıları araştırılmıştır.

\section{Bulgular}

\section{1. Çal'da Başlayan Türk Sanatının Güneşi}

\section{Görsel 1}

Cormon Atölyesi

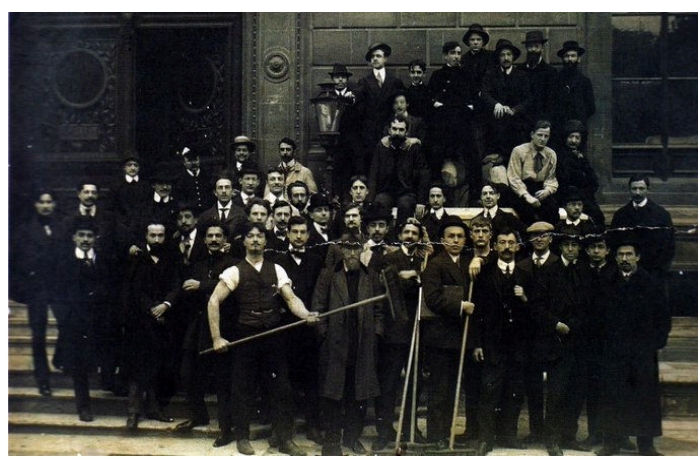

(TweetDeck, 2019)

Avrupa yarışmasını kazanan Çallı, 1910 yılında Paris’e gitmiştir. Paris’te Güzel Sanatlar Okulu’na yazılmış ve orada dört yıl boyunca Fernand Cormon'un atölyesinde çalışmıştır. Eğitimini tamamladıktan sonra 1914 yılında Paris'te beraber eğitim aldığı arkadaşları Ruhi Arel ve Hikmet Onat'la birlikte Türkiye'ye geri dönmüştür (Berk, 1974, s. 460).

Gelenekçi, sözde bir klasisizmin peşinde koşan Cormon’un en sevdiği konular arasında tarih öncesi yaşantılar, Yunan ve Roma tarihi başta geliyordu. Cormon'un dikkatli bir öğrencisi olan Çallı ve arkadaşları I. Dünya Savaşının başlaması ile birlikte ülkeye dönerek Halil Paşa'nın aracılığı ile Akademiye hoca olmuşlardır. Bu büyük sanatçılardan oluşan grup ilk sergilerini 1919 yılında Beyoğlu'nda Galatasaraylılar Yurdu'nda açmışlardır. Bu grup, daha sonraları grubun şefi durumunda bulunan Çallı'dan dolayı "Çallı grubu" ismi ile anılır hale gelmiştir. Emekli olduğu 1947 yılına kadar Sanayi-i Nefise Mektebi'ndeki görevine devam eden sanatçı bu tarihten ölümü olan 1960 tarihine kadar sanat hayatına devam etmiştir. Arkadaşları ile birlikte sanat tarihimize "Türk Empresyonistleri' olarak geçen Çallı Grubu, bizde empresyonizmin temsilcisi sayılmaktadır. 1919 yılında açtıkları sergi, zaten empresyonizmin öncülügüünü yaptıklarını göstermektedir ki bu, Türk resim sanatı bakımından son derece önemlidir (Büyük Ressamlar Ansiklopedisi, 1968). Sanatçının gördüklerinin kendisinde uyandırdığg duygu ve düşünceleri yani izlenimlerinin yansıtılması olarak ifade edilen İzlenimcilik (empresyonizm) kendisinden sonra gelen birçok sanat dalını etkilemiştir. Bu akımdan etkilenen Çallı da bu türde ilk örnekleri empresyonist bir teknikle 1924'lere kadar vermiştir.

Empresyonistler prensip olarak doğa ile doğrudan bağ kurmak ve resmin daha gerçekçi görünmesi için atölye yerine resmi açık havada yapmışlardır. Koyu, karanlık, siyah tonlar yerine açık ve ferahlık veren tonları resimlerinde kullanmışlardır (Ayaydın 2015, s. 89) Bu akımdan etkilenen Çallı' da da renklerin açık ve parlaklığı göze çarpmaktadır. Bu yönünle bir doğa ve açık hava ressamıdır. Ayrıca portre, peyzaj, natürmort ve nü’lerinde döneminde yaygın olarak kullanılan kalıpları yıkan bir tavır sergilemiştir” (Başbuğ, 2010, s. 371). Çallı'nın manolyaları, peyzajları, nü'leri yanında bu resmin dengeli kompozisyon düzeni, doğru çizimleri, ayrıntılardan çok bütüne önem verişiyle İzlenimci bir anlatım içinde akademik disipline bağlılığını da göstermektedir (Ersoy, 2004, s. 145).

Çallı, serbest tuşlar ve bir ölçüde de özgür çalışma temposuyla izlenimciliği en güzel şekliyle yansıtmıştır. Konuyla ilgili olarak Nurullah Berk "1914 yılından beri tezahür eden ve İmpressionniste kaidelerin akademikleşmiş formülüne dayanan sanatı temsil eden grubun önde gelen sanatçılarından biriside Çallı'dır” der (Sarı, 1994, s. 58). (Görsel 2). 


\section{Görsel 2}

Atatürk

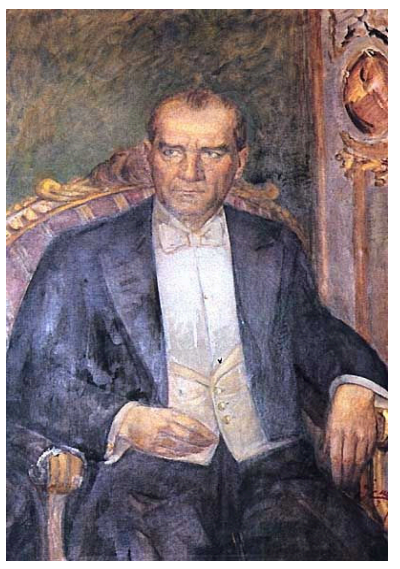

(Çalli, 1934)

Çallı, resmin her alanında çok başarılı örnekler vermiştir. Cami Avlusu, Mevleviler Serisi, Dikiş Diken Kadın, Zeybekler Kurtuluş Savaşında, Türk Topçularının Mevziye Girişi, Nü, Balıkçı Kayığı, Çayır ve Keçiler, Atatürk ve İnönü, Yahya Kemal Portreleri, Lüxemburg Bahçesi'nin yanı sıra son dönemlerinde portre ve düzenlemelerinden uzaklaşarak kendini çiçekler ve manolyalara verdiği günlerde, ürettiği manolyalar önemli eserler arasinda sayılırlar (Meydan Laurousse, 1990, s. 129) (Görsel 3).

\section{Görsel 3}

Emirgân

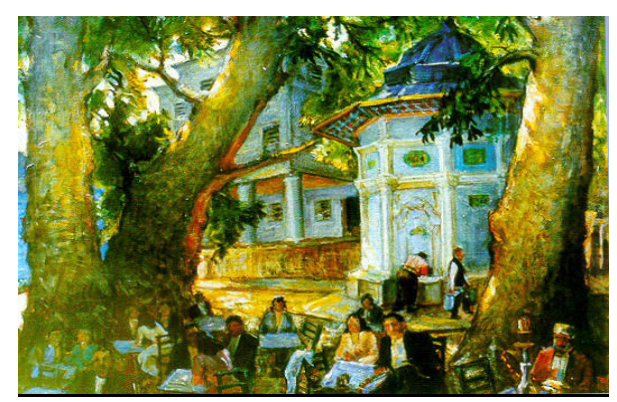

(Çall1, 1937)

Çallı, "Zeybekler Kurtuluş Savaşında" adlı ünlü resminde, izlenimci yönü ön plana çıkarak, gerçeği yansıtmak yerine, gördüklerinin kendisinde canlandırdığı duygu ve düşünceleri yorumlamıştır. İstiklal Savaşı'nda vatanı kurtarmaya koşan zeybekleri Çallı 1924 yılında yapmıştır. Resme kattığı yorum onun kişiliğinin bir yansımasıdır. Resimde dört efenin savaşa uğurlanması, kadınların Türk aile yapısını yansıtması, Anadolu insanının özellikle de Türk kadınlarının hayat mücadelesini yansıtması açısından önemlidir. Bir savaş dönemini yansıtan bu eser, izleyicisine huzur ve mutluluk vermektedir. Savaş esnasında gösterilen kahramanlıklar, fedakarlıklar, halkın bir bütün olarak yaptığı mücadeleleri betimlemektedir. Resimdeki renklerin kullanımı, parlaklık ve canlılığı açık hava resminin tüm özelliklerini bünyesinde barındırır. Kurtuluş savaşındaki halkın vermiş olduğu olağanüstü mücadeleyi resmederek ölümsüzleştiren Çallı, bu resmiyle hem onları hem de büyük mücadeleyi onurlandırmıştır (Alkan ve Kahraman, 2016, s. 18) (Görsel 4).

\section{Görsel 4}

Zeybekler Kurtuluş Savaşında

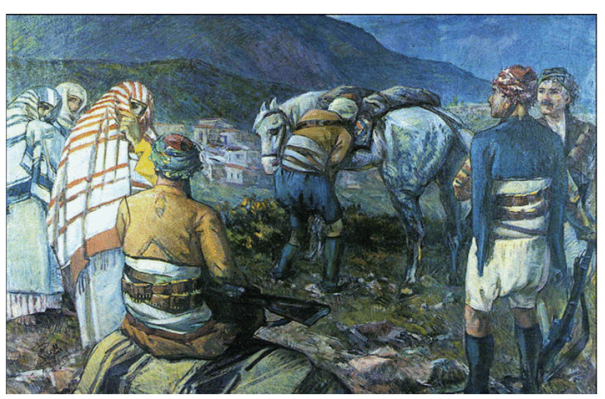

(Çall1, 1923) 
Zeybekler tablosu, Kurtuluş Savaşında cefakâr Anadolu halkının bağımsızlık ve kurtuluş özlemini, ellerinde tüfekleriyle vatan savunmasına gitmek üzere hazırlanan zeybeklerle, onları uğurlayan Anadolu kadınlarını gösterir. Kurgusu ve kompozisyonuyla işlek, zorlamasız, geniş firça darbeleri ve sıcacık renkleriyle empresyonist tarzda bir eserdir. İbrahim Çallı'nın tüm resimlerinde bu sıcacık renkleri görmek mümkündür. Hatta portrelerinde bile sarı, turuncu tonlarını savruk firça darbeleriyle ustaca tuvale aktarmıştır (Kaman, 2015). Yenilikçi ve yaratıcı bir sanatçı olan Çallı, bu dönemde İstanbul'a gelen Ukraynalı sanatçı Alexis Gritchenko ile tanışmış ve arkadaş olmuştur. Gritchenko, 1919 ve 1921 yılları arasında çoğu suluboya, guaş, yağlıboya ve karakalem çalışmalarından oluşan eserler vermiştir (Görsel 5).

\section{Görsel 5}

Dans Eden Dervişler

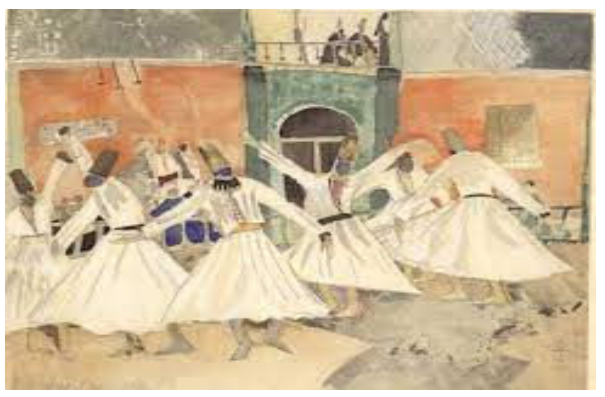

(Gritchenko, 1920)

İstanbul'u ve oradaki kültürel hayatı konu alan bu eserler Çallı'nın dikkatini çekmiştir. Gritchenko ile olan etkileşim neticesinde Çallı, empresyonist tekniğini terkederek, grafiğe yakın, şematik ve karışık olmayan bir renk stilini benimseyip uygulamıştır. Bu resimlerde Çallı; detaylardan arınmış düz renklere yönelmiştir (Giray, 2007, s. 140). Ancak bununla birlikte Mevleviler serisi Çallı'ya, anlatımı cesaretli ve plastik karakteri açısından yeni bir üslup kazandırmıştır (Berk ve Turani, 1981, s. 26). Bu yeni üslubunda ayrıntıların yerini büyük lekesel yorumlar, 1şık yerine ise geometrik dağılımlar, devinim yerine de statik dengelere ağırlık veren yeni bir tarz benimsemiştir (Giray, 2007, s. 112). Bu üslup değişimi, onun karakterinin olgunluğunu göstermektedir. (Berk ve Gezer, 1972, s. 27). Çallı'nın Mevleviler çalışmalarını bakıldığında bu ritüel ayinleri sürekli olarak incelediği ve olayı kendi mekanlarında Mevlevihanelerde tasarladığı bu mekanlardaki figürler ve mana alemindeki felsefi görüşlerini yansıtılması doğru bir gözlem ve dışa vurum olarak resimde yansımaktadır (Görsel 6).

\section{Görsel 6}

Mevleviler

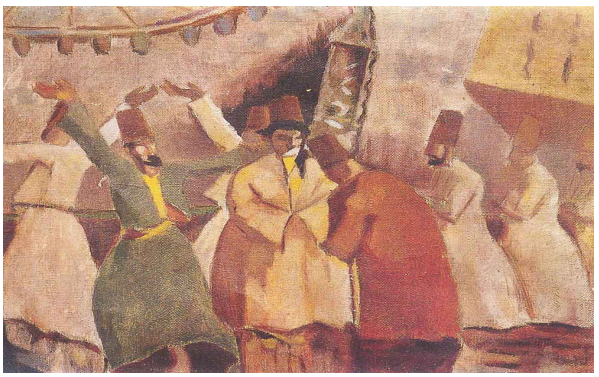

(Çallı, 1927)

\subsection{Sanatçı ve Eleştirmenlerin Gözü ile İbrahim Çallı}

Avrupa'da akademikleşmeye yüz tutan bir anlayışı yansıtması nedeni ile Çallı'nın sanatını akademik izlenimci bir çizgide görmek daha doğru bir görüş olacaktır (Özel, 1971, s. 44). Empresyonist üslupta konunun önemi, doğru çizimi, perspektif ve deseni fazla önemsenmez anlayışına karşılık, Çallı'da bunların herbiri ayrı bir öneme sahiptir. $\mathrm{Bu}$ yönüyle Çallı, izlenimcilik ile akademizmi birleştirerek yeni bir üslup geliştirmiştir. Çağın diğer sanat akımlarının gerisinde kalmayan Çallı için ressam Zeki Faik İzer, 'Fransa'da Rosulı ve Matisse ne ise Türkiye'de Çallı aynı rolü oynamıştır" (Arseven, 1975, s. 186) derken empresyonizm ve modern resmin ülkede yayılmasına öncülük eden sanatçının plastik dehasını realist bir şekilde vurgulamıştır. Paletindeki canlılık doğa etütlerinde temeldeki değişmezlik, ayrı öbekler halinde toparlayabilme, tüm resimlerindeki (özellikle manolyalar) değişmeyen bir özelliktir. Renkleri son derece canlı ve hoştur. Çallı' da 1şıklar sarı-turuncu iken gölgeler genelde mor ve mavidir. Işık ve gölge Çallı' da tamamen kendine özgü bir ritim armoni oluşturmakladır. Bunun yanı sıra eserlerinde siyah renk yok denebilecek kadar az kullanılmıştır (Özel, 1971, s. 44) (Görsel 7). 


\section{Görsel 7}

Manolyalar

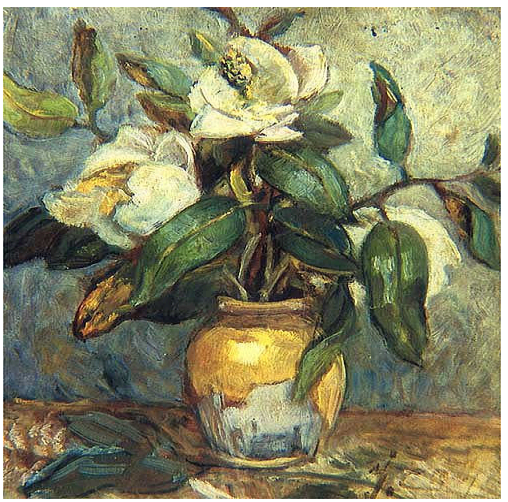

(Çallı, 1933)

Nereye hangi rengi sürse, orantılı, güzel ve tatlı olmuş, en önemsiz etüdü, taslağı boyalı krokisi renk armonileriyle gözü okşayan bir sanat eseri halini almıştır. Birçok eserinde gözlemlenebilen düzensizlik ve kuruluş eksikliklerine rağmen bu resimlerin çekiciliği bir anda seyredenleri saran, gözü okşayan sıcaklığı, o yetersizlikleri unutturabilmektedir (Berk,1974, s. 27) (Görsel 8).

\section{Görsel 8}

Rumeli Hisart

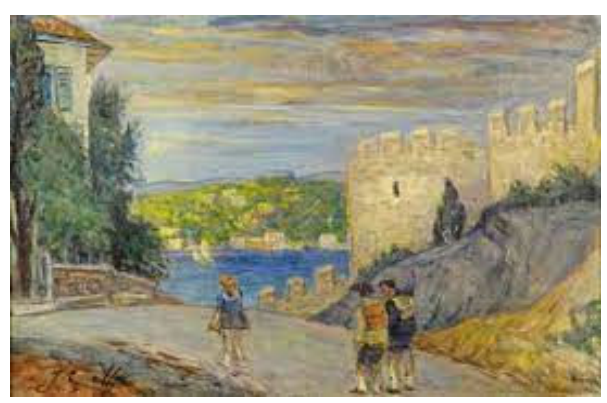

(Çallı, 1941)

1914 kuşağına Çallı kuşağı denmesinin nedeni Çallı’nın bir sanatının yanı sıra esprili konuşma tarzı ve bohem hayatı ile ün yapmış popüler bir sanatçı olması da gösterilebilir (Tansuğ, 1991, s. 120). Olağanüstü bir kültürü bulunmamasına rağmen, bir filozof kadar hayatın içeriğini kavrayabilmiş, doğanın güzellikleri âşık olmuş bir sanatçı olan Çallı, içine kapanık olmayan sofra sohbetlerine düşkün, toplantıları renklendiren, sıcak sevimli bir kişiliğe sahipti (Berk ve Gezer,1972, s. 26). Münakaşaları seven, kendi fikirlerini ön plâna çıkarıp kabul ettirmeye çalışan bir kişilik sahibi olan sanatçının hayatı, menkıbelerle doludur. Bir gün Beyoğlu'ndan Haliç'e inen Çallı, sabaha karşı Akademideki odasına oldukça içkili olarak dönerken, yolda karşısına çıkan soyguncular tarafından elbiselerine varıncaya kadar soyulmuştur. İç elbiseleri ile ortada kalan Çallı, yoluna devam ederken bu kez de polisler tarafından yakalanır. Kimlik kontrolü yapılıp sorguya çekilen Çallı "ben profesörüm” demişse de polisleri ikna edemez. Deli olduğuna kanaat getirilip, karakola götürülen ve akıl hastanesi için müzekkere hazırlanan Çallı, bu sırada kendine gelir; “beni önce akademiye götürün kim olduğumu anlarsınız, eğer isterseniz Atatürk'e sorun o size kim olduğumu söyler” deyince polisler onu Akademiye götürerek gerçeği anlamış ve serbest bırakmışlardır (Arseven, 1975, s. 188).

1914 kuşağına Çallı kuşağı denmesinin nedeni Çallı’nın bir sanatının yanısıra esprili konuşma tarzı ve bohem hayatı ile ün yapmış popüler bir sanatçı olması da gösterilebilir (Tansuğ, 1991, s. 120). Çallı açık havada yaptığ resimlerinde manzara, figür, portre, natürmort ve nü gibi konuların yanında İstanbul sokak ve çay bahçelerini, ada ve tekne gezintilerini ve eğlenceli vakit geçiren kadınları da konu olarak seçmiştir (Görsel 9). 


\section{Görsel 9}

Adada Piknik Sefası

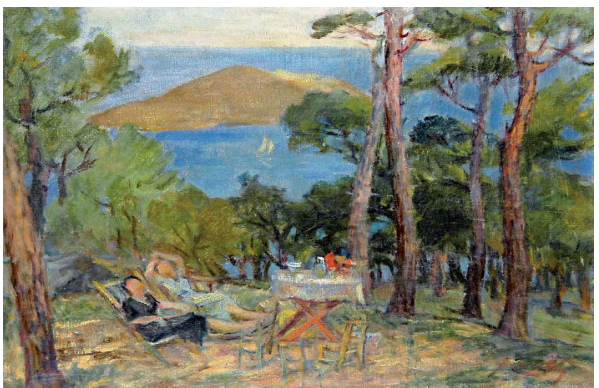

(Çallı, t.y.a)

Bu yönüyle iyi bir gözlemci olan Çallı yaptı̆̆ı resimlerle 1914 sanatçıları arasında adı en çok bilinen sanatçıdır. Yaptığı resimlerinde renklerle oynaması, tablolarına fazla önem vermemesi onun sabırsız bir sanatçı olduğunu gösterebilir. Çallı her zaman kendine özgü eserler vermiştir. Bu eserleri verirken de kendini, eğitimini sürekli sorgulamış, yeni akım ve üslupları denemiştir. Bu durum onun ressamlar arasında büyük bir üne kavuşmasına sebep olmuştur. Belki de bu yüzden 1914 Kuşă̆g'na Çallı Kuşă̆ da denilmiş olabilir (Baytar ve Okkalı, 2020, s. 135). Paris'te L'Ecole des Beaux Arts'ta Fernand Cormon'un atölyesinde eğitim alan Çallı, Fransız izlenimciliğinin etkisiyle açık havada canlı ve ışıklı renkler, gün ışığında doğal görünümler, nü ve portre konulara ağırlık vermiştir. (Görsel 10-11).

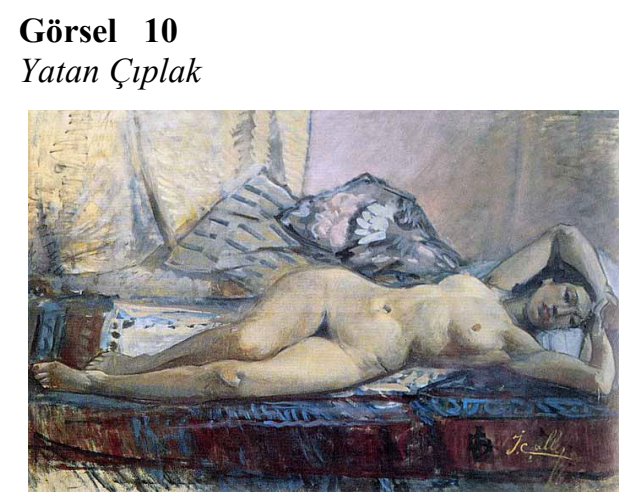

(Çallı, t.y.b)

\section{Görsel 11}

Yatan çılak

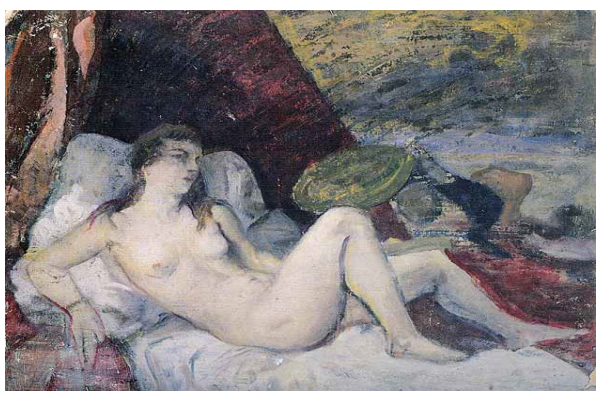

(Çallı, t.y.c)

Bu yönüyle Batıya yönelik resim anlayışımızı kökünden değiştiren bir cüret sergilemiştir. Bu nedenle yurdumuzda yeni bir çı̆̆ırın temsilcisi olmuştur. Bu yeni bakış açısıyla meydana getirdiği eserlerini İstanbul'da Galatasaray Yurdu'nda sergilemiştir. Sanatçı bu sergiden sonra da çeşitleri konulardaki çalışmalarını düzenli olarak Galataray ve Devlet Resim ve Heykel'de sergilemiştir (Turani, 1984, s. XXVIII; Bayav, 2016, s. 37).

Çallı kuşağı sanatçılarının Cumhuriyet dönemi ile bağlantılarına en geçerli kanıt, Atatürk, İnönü ve Fevzi Çakmak portrelerinin en önemli ve değerli olanlarını gerçekleştirmiş olmalarıdır. Bu portrelerin tümünde derin bir güven ve inancın payı vardır (Tansuğ, 1991, s. 120). 1914 Çallı Kuşağı dönemi, batılı anlamdaki resmi almış oldukları eğitimin bir sonucu olarak bugünkü anlayışımıza en yakın biçimde yorumlayan bir dönemdir. Zira Türk İzlenimciliği'nin en güzel örnekleri bu dönem sanatçılarının ürünlerinde görülür. Özellikle Çallı'nın batı resim 
anlayışına ağırlık vermesi, bu kuşağın Türk resim alanında itici bir güce dönüşmesine sebep olmuştur. Kıymet Giray’a göre “1914 Kuşağı”na ismini veren Çallı'nın resim yapma tutkusu, yaşama sarılması, sanatçı ruhu, eşsiz bir öğretmen olması ve kendinden sonra gelen bir ressam kuşağı yetiştirmesi açılarından son derece kıymetli bir ressamdır. Ona göre Çallı demek "ressam" demektir. Çallı atölyesinde kendi sanatını değil resim yapmayı ve sanatçı olmayı öğretmiştir. Öğrencilerine gerekli bütün teknik ve resimsel değerleri, sanat kültür ve tarihini içten ve yapmacıksız bir şekilde öğretmiştir. Sanatçı kimliğinin yanısıra, sanat camiası ile kurduğu yakın ilişki, çevresinde yarattı̆̆ı sinerji onun sanatçı kimliğini yansıtmaktadır. (Giray, 2001, s. 78-81) (Görsel 12).

\section{Görsel 12}

Ibrahim Çallı Atölyesi Ders Esnasinda (1930)

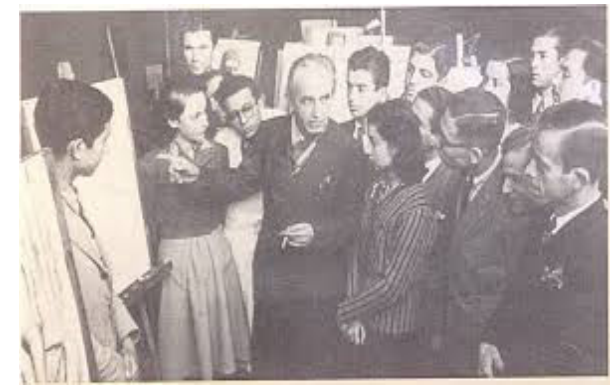

(Kültür İstanbul, 2021)

Çallı'nın doğuştan gelen yeteneği ve yaratıcılığını iyi bir eğitimle birleştirmesi, açık fikirli olması, doğanın güzelliklerini özgürce kullanması, hazırcevaplığı, sıcak kanlılığı, olabildiğine renkli yaşamı onun ressam mizacını oluşturmaktaydı. Bu mizacı şüphesiz eserlerine de yansımıștır. Çallı, bir koloristtir. Bu nedenle de rengi bir anlatım aracı haline getirmiştir. Resimlerinde kullandığı çok renk ve renk sıcaklıkları, ışıkların yansıtılması, desenciliği, yoğun bir boya dokusu, mekân ve kurgusal yaklaşımları, öznel dokunuşları resminin toplam değerini ortaya koymaktadır ki onun mizacı, onu ağırbaşlı ve disiplinli çalışmalardan uzaklaştırmıştır. Onun, resmin kuruluş ve desenindeki yetersizliği, renkleri kullanmadaki aceleciliği, amaca varamayan atılganlığı göze çarpan ilk kusurlarıydı. Ancak onun kolorist yapısı bu kusurları örtmüştür. $O$ renk güzelliğini desen düzgünlüğü ile birleştirmeyi başarmıştır (Berk ve Gezer, 1972, s. 26).

\section{Sonuç}

Bütün hayatı boyunca devamlı bir sanat heyecanına sahip olan Çallı, yine bu heyecanını kamçılamak için içkiye başvurmuştur. Yine çocukluk yılarına ait anılarının birinde, resim tutkusunun çocukluğunda başladığı, evin duvarlarına tebeşir ve kömürle resimler yaptığı için, babasından çok defa dayak yediğini, bu durumun 17 yaşında İzmir'e gidinceye kadar devanı ettiğini öğreniyoruz. Bu yıllarda İstanbul'a gelen Alexis Gritchenko isimli ressamın İstanbul cami ve tekkelerinden yaptığı guvaj ve suluboya resimlerin Çallı'nın dikkatini çekip bu sanatçı ile arkadaş olması onun sanatının olgunlaşmasını sağladığı gibi sanattaki yeniliklere açık olduğunu da göstermektedir. Bu karşılaşma Çallı'da bundan sonraki çalışmaları için yeni bir üsluba yöneliminin zeminini oluşturmuştur. Çallı, Tevfik Fikret, Yahya Kemal, Neyzen Tevfik, Tamburi Cemil Bey, Dede Efendi gibi iç dünyamıza işlemiş insanımızdır. Detaydan daima kaçan sanatçı, çalışmalarında lirik, coşkun diyebileceğimiz romantik eğilimli bir yön tutmuştur. Desen yetersiz olmasına karşılık desenin üzeri öylesine hoş renklerle örtülmüş taşkın mizacı, yetersiz çizgi sistemine öylesine çekici bir şekilde kaybettirmiștir ki hataların hemen hepsi kayıp olmuş, tablo tümde bütünleşmiştir (Büyük Ressamlar Ansiklopedisi, 1968).

Başta Resim ve Heykel Müzeleri, Bankalar özel ve resmi koleksiyonlar olmak üzere birçok yerde eserleri bulunan İbrahim Çallı, günümüz Türk resim sanatının gelişip büyümesinde tartışılmayacak payı bulunan öncelikli sanatçılarımızdandır. İbrahim Çallı, zamanının sanat anlayışı gereği olarak kadın konusuna çok girmemiş Türk resmine çıplak kadın resimlerini sokmuştur. Yine Feyhaman Duran, portreyi Türk resmine sokmuş ya da en azından yerleştirmiştir. Ankara Devlet Resim ve Heykel Müzesi'ndeki "Çıplak" adlı resmi ise, o zamana değin kadın konusuna girmekten çekinen Türk resmine çıplak kadın figürünün ilk uygulanmasıdır. Türk resminin ilk çıplak modelli tablolarını yapan Çallı'nın resimleri, desen yönünde önem vermeden âdeta çırpıştırılmış, belli bir formüle bağlı kalmadan bir iki seansta oluşturulmuş hissini yaratır (Büyük Ressamlar Ansiklopedisi, 1968, s. 42). Çallı, Türk resmine getirdiği yeni solukla kendi kuşağının gözde bir temsilcisi konumuna yükselmiştir. O, yaptığ resimlerinde tablonun düzenine, çizgisel yapısına, çok fazla önem vermemiștir. Renklerle özgürce oynaması, aceleci fırça darbeleri ile yaptığı resimler onun aceleci kişiliğinin sanat anlayışına yansımıştır. Resimlerinde konu ayrımcılığı yapmamış, bütün konuları denemiştir.

İbrahim Çallı, Türk resmine Empresyonizm'i yerleştiren 1914 kuşağı sanatçıları arasındadır. Çallı'nın manolyaları, peyzajları, nüleri yanında bu resmin dengeli kompozisyon düzeni, doğru çizimleri, ayrıntılardan çok bütüne önem verişiyle İzlenimci bir anlatım içinde akademik disipline bağlılığını da göstermektedir. Çallı'nın aldığı eğitim ve 
yetiştiği çevre, hayata olumlu bakışı, insanlarla sıcak ilişkisi sanatına da yansımıştır. Bu durum resimlerindeki renklerin kullanımında, kompozisyonunda kendini göstermektedir. Resimlerdeki kurgu onun hem zekâsını, hem bilgisini hem de hayatla iç içe olduğunu en canlı şekilde ortaya koymaktadır.

Çallı, Mevleviler serisini oluştururken izlenimci teknikten farklı olarak daha şematik ve az karışımlı renk anlayışı ile daha etkili ve vurgulayıcı eserler ortaya koymuştur. Çallı, 1923'ten sonra Kurtuluş Savaşı ve Atatürk'ün gerçekleştirdiği devrimlerle ilgili kompozisyonlar yapmış, Atatürk portreleri ve Anadolu insanını, köy hayatını anlatan büyük boyutlu resimler çalışmıştır. Ayrıca eserlerinde manzara resimleri, ölü doğa ve portre tarzı resimlere de ağırlık vermiştir. Çallı doğuştan büyük bir sanat duygusuna ve yeteneğe sahipti. Toplantılarda fikirlerini özgürce açıklar, hiç kimseden çekinmeden ve düşündüklerini açıkca söyleyen bir karaktere sahiptir. Başlangıçta sahip olduğu batı anlayışı sebebiyle karşı çıktığı resimlere daha sonraları daha toleranslı olmuştur. Örneğin Mevleviler dizisi, Çallı'nın modernist sanat anlayışı ile pek uyuşmamaktadır. Farklı konularda, farklı üsluplarla eser vermesi, Osmanlı'dan Cumhuriyet'e değişen sanat anlayışını ortaya koymaktadır. Çallı' daki değişim, Türk Resim Sanatının geçirdiği değişimin ta kendisidir. Bu yönüyle Çallı, Türk Resim Sanatı'nın değiş̧im süreçlerine ayna tutabilir.

Eserlerinde ağırlıklı olarak kullandığı yeşil ve kahverengiler Çallı’nın en çok sevdiği renkler olmakla beraber, açık hava resimlerinde kullandığı uygulama şekli ile renklerdeki parlaklık ve saydamlığı başta gelen özelliklerinden olmuştur. Eserlerindeki çağdaşlık dönemin sanatçılarına da yansımış, onlara örnek teşkil eden bir sanatçı olarak, çağdaş Türk resminin kurucusu Çallı demek yanlış bir değerlendirme olmayacaktır. Eşref Üren'in de belirttiği gibi: "Ressam İbrahim Çallı demeğe lüzum yoktu. İbrahim'i de kaldırabilirdiniz. Bir 'Çallı' demek aklımıza hemen ressamı getiriyordu. Türk resminde onun kadar halka malolmuş bir ressamımızı hatırlamıyorum (Giray, 2001, s. 79). Çallı, resim sanatında portre, natürmort, peyzaj ve nü çalışmaları ve desen düzgünlüğü ile kullandığı renklerin güzelliğini eserlerinde en iyi şekilde birleştirebilen Türkiye'nin yetiştirmiş olduğu nadir sanatçılardan olduğunu her zaman kanıtlamış örnek alınması gereken büyük bir üstattır.

\section{Kaynakça}

Alkan, U., \& Kahraman, M. E. (2016). İbrahim Çallı'nın Kurtuluş Savaşı temalı resimlerinin ikonografik ve ikonolojik incelenmesi. Kalemişi, 4(7), 1-18. https:/www.kalemisidergisi.com/makale/pdf/1454360063. pdf

Arseven, C. E. (1975). İbrahim Çallı. Türk sanat tarihi cilt III içinde. Milli Eğitim Basımevi.

Ayaydın, A. (2015). Empresyonizm (İzlenimcilik) akımının güncel bakış açısıyla bazı yönlerden incelenmesi. Sanat Eğitimi Dergisi, 3(2), 83-96. https://doi.org/10.7816/sed-03-02-05

Başbuğ, F. (2010). 1914 Çallı kuşağının Türk resim sanatına etkisi. Selçuk Üniversitesi Ahmet Keleşoğlu Eğitim Fakültesi Dergisi, 29, 371-392. https:/www.academia.edu/8732110/1914_\%C3\%87all\%C4\%B1_Ku\% C5\%9Fa\%C4\%9F\%C4\%B1n\%C4\%B1n_T\%C3\%BCrk_Resim_Sanat $\%$ C4\%B1na_Etkisi

Bayav, D. (2016). Batılı sanatçıların Çallı kuşağı'na etkileri. Sanat Tarihi Dergisi, Aralık, 27-53. https://dergipark.org.tr/tr/download/article-file/567321

Baytar, İ., \& Okkalı, İ. C. (2020). Gelenekten beslenen modernlik: İbrahim Çallı ve Mevleviler serisi. Atatürk Üniversitesi Güzel Sanatlar Enstitüsü Dergisi, 26(44), 126-137. https://doi.org/10.35247/ataunigsed. $\underline{659286}$

Berk, N., \& Gezer, H. (1972). 50 yılın Türk resim ve heykeli. Türkiye İş Bankası Yayınları.

Berk, N. (1974). İbrahim Çallı. Türkiye (1923-1973) ansiklopedisi (Cilt 2) içinde. Kaynak Kitaplar.

Berk, N., \& Turanî, A. (1981). Başlangıcından bugüne Türk resim sanatı tarihi (Cilt 3). Tiglat Basımevi.

Berk, N., \& Özsezgin, K. (1983). Cumhuriyet dönemi Türk resmi. Türkiye İş Bankası Yayınları.

Büyük Ressamlar Ansiklopedisi. (1968). Çallı. Büyük ressamlar ansiklopedisi fasikül 3 içinde. Hayat Yayınları.

Çallı, İ. (1923). Zeybekler Kurtuluş Savaşında [Resim]. Pinterest. https://tr.pinterest.com/pin/5217843068099605 $\underline{87 /}$

Çallı, İ. (1927). Mevleviler [Resim]. Pinterest. https://tr.pinterest.com/pin/521784306809960596/

Çallı, İ. (1934). Atatürk [Resim]. Pinterest. https://tr.pinterest.com/akerdemmangalog/ibrahim-\%C3\%A7 all $\% \mathrm{C} 4 \% \mathrm{~B} 1 /$

Çallı, İ. (1937). Emirgân [Resim]. Pinterest. https://tr.pinterest.com/pin/369435975657999764/

Çallı, İ. (1941). Rumeli hisarı [Resim]. Pinterest. https://tr.pinterest.com/pin/501799583466124021/ 
Çallı, İ. (t.y.a). Adada piknik sefası [Resim]. Pinterest. https://tr.pinterest.com/pin/403987029072104835/

Çallı, İ. (t.y.b). Yatan çılak [Resim]. https://tr.pinterest.com/pin/393150242452416006/

Çall, İ. (t.y.c). Yatan çıplak [Resim]. https://tr.pinterest.com/pin/514606694895999715/

Ersoy, A. (2004). 500 Türk sanatçısı: Plastik sanatlar. Altın Kitaplar Yayınevi.

Eyüboğlu, B. R. (1976). Çallı üzerine. Türkiyemiz, 18, 7-14.

Giray, K. (2001). Çallı ve atölyesi. Türkiye İş Bankası Yayınları.

Giray, K. (2007). Türk resim sanatının bir asırlk öyküsü. Akbank Yayınları.

Gritchenko, A. (1920). Dans eden dervişler [Resim]. Mavi Boncuk. http://maviboncuk.blogspot.com/2020/02/ alexis-gritchenko-centenary-exhibit-in.html

Kaman, S. (2015). Görsel çözz̈mleme/ 'Zeybekler'. Salime Kaman. https://salimekaman.wordpress.com/2015/03/ 28/gorsel-cozumleme-zeybekler/

Kültür İstanbul. (2021). İbrahim Çallı Atölyesi Ders Esnasında (1930) [Fotoğraf]. kültür.istanbul. https://kultur.istanbul/yasamindan-notlar-ve-eserleriyle-ibrahim-calli/

Meydan Laurousse. (1990). Çallı. Meydan laurousse alfabetik genel kültür ansiklopedisi Cilt 3 (s. 129) içinde. Meydan Yayınevi.

Özel, M. (1971). Sanat dünyamız'nn solmayan güneşlerinden İbrahim Çallı. Kültür ve Sanat. Aralık. Sayı 3.

Papila, A. (2008). Osmanlı İmparatorluğu'nun batılılaşma döneminde resim sanatının ortaya çıkışı ve Osmanlı kimliğinin resimsel anlatımı. Sanat ve Tasarım Dergisi, 1(1), 117-134. https://dergipark.org.tr/tr/ download/article-file/192618

Sarı, S. (1994). Ressam İbrahim Çallı'nın hayatı, kişiliği ve sanatı (Tez No. 30460) [Yüksek Lisans Tezi, Selçuk Üniversitesi, Sosyal Bilimler Enstitüsü]. Yüksek Öğretim Kurulu Tez Merkezi.

Tansuğ, S. (1991). Çağdaş Türk sanatı. Remzi Kitapevi

Turani, A. (1984). Batı anlayışına dönük Türk resim sanatı. İş Bankası Kültür Yayınları.

TweetDeck. (2019). Cormon atölyesi [Fotoğraf]. Twitter. https://twitter.com/oart7218/status/1090918864882348 $\underline{033}$ 